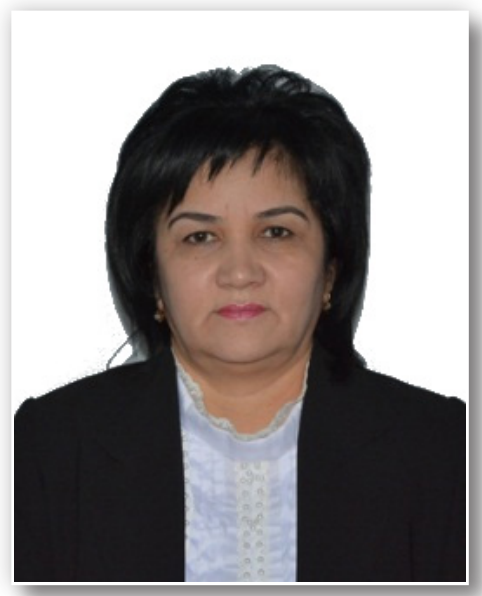

Dilbar Abdullaeva,

$\mathrm{PhD}$ in Psychology,

Associate Professor of the Department of Practical

Psychology,

Tashkent State Pedagogical University named after Nizami,

Tashkent, Republic of Uzbekistan.

ORCID: https://orcid.org/0000-0002-8564-0378

УДК 159.9:316.37

DOI https://doi.org/10.32405/2309-3935-2021-1(80)-51-54

\title{
CORRELATION OF MOTHERS WITH DIFFERENT IDEAS ABOUT THE SOCIAL ROLES OF WOMEN
}

Summary.

The article considers the problem of child-parental relations in the context of the individual psychology of mothers. Empirical evidence reveals the role of mothers' perceptions of women's social roles in determining their attitudes towards children. According to the data obtained, the relationship between the prevailing styles of child-parental relations and the ideas of mothers about a woman in the role of a "housewife" and a "socially active person" is proved.

Controlling human behavior in interpersonal interaction is a psychological process with most complex internal mechanism. The quality of this control depends on many social and individual psychological factors. Undoubtedly, the style of behavior that people choose to interact largely depends on the social and natural conditions in which it unfolds. At the same time, it must be recognized that values, ideals, communicative abilities, and psychological problems of the person play an important role in this choice. One of these most important subjective factors that determine the characteristics of interpersonal interaction is the requirements of social roles, being the owners of which people enter into interaction. Indeed, it is often the demands of a social role that acts as a regulator that induces one action and stops others.

In child-parental relations as a special type of human-human relationship, the factor of social roles is also important. The results of a number of psychological studies suggest that even at the level of ideas about social roles, the meanings of this factor in the relationship between parents and children can be traced, which is also shown by the results of our studies.

Key words: ideas; psychological factor; social role; teenage children; child-parental relations; maternal attitude.

Controlling human behavior in interpersonal interaction is a psychological process with most complex internal mechanism. The quality of this control depends on many social and individual psychological factors. Undoubtedly, the style of behavior that people choose to interact largely depends on the social and natural conditions in which it unfolds. At the same time, it must be recognized that values, ideals, communicative abilities, and psychological problems of the person play an important role in this choice. As you know, one of these most important subjective factors that determine the characteristics of interpersonal interaction is the requirements of social roles, being the owners of which people enter into interaction. Indeed, it is often the demands of a social role that acts as a regulator that induces one action and stops others.

In psychological science, the concept of "social role" is defined as a normative system of actions based on what place a person occupies in the structure of social relations [7, p. 383]. In fact, the social role is a system of requirements that it is desirable or mandatory to comply with under certain conditions $[3 ; 4]$. In other words, the social role determines the vector of behavior in interpersonal relations, performs the function of a social controller $[7 ; 8]$.

Of course, in child-parental relations as a special type of human-human relationship, the factor of social roles is also important. The results of a number of studies suggest that even at the level of ideas about social roles, the significance of this factor in the relationship between parents and children can be traced. For example, K. Belogaya proves that the leading part of the emotional component of the maternal relationship, which is central to it, is the mother's feelings about role and satisfaction with it [1]. F. Zimbardo and P. Gehrig presented the data of the experiment, according to which young people who could better imagine themselves as a parent more positively evaluated infants represented in different (calm, neutral, nervous) states on video frames [2]. The famous researcher of the psychology of parenthood R. Ovcharova draws attention to the fact that the attitude of parents towards children largely depends on how they accept and understand parental 
role. At the same time, this role may be perceived by them as an opportunity or as an obstacle to the realization of personal opportunities. According to R. Ovcharova, those parents who perceive the parental role as an obstacle to self-realization are characterized by an orientation towards the intended future or past in relations with the child, which sooner or later will lead to a violation in child-parental relations [5, p. 31-32; 6, p. 46-47].

Thus, the data of various studies indicate the significance of ideas formed about certain social roles in establishing interpersonal relations, including in terms of relations between parents and children. However, a special study aimed at examining the impact of the mother's ideas about social roles on her attitude towards children has not yet been conducted, which led us to organize empirical work in this direction. The general algorithm for empirical research consisted of the following steps:

1) among mothers (total 124 respondents) with children of the same age (adolescent), a sociopsychological survey was conducted through the methodology "Questionnaire of child-parental relations" (A. Varga, V. Stolin);

2) with the help of a special author's questionnaire, a procedure was carried out to identify the ideas of mothers about two social roles, conditionally designated as "the role of a housewife" and "the role of a socially active woman";

3 ) the results of two parallel measurements were compared and analyzed through quantitative and qualitative analysis methods (mathematical statistics and psychological interpretation methods).

The research work carried out in the order described above revealed the specific relationships between mothers' perceptions of social roles characteristic of modern women and their preferences regarding the style of interaction with teenage children. Starting the discussion of the results, it should be noted first of all that the majority of women $(61 \%)$ gave preference for the perception of a woman as a "housewife," although initially the sample of subjects consisted of an equal number of women working exclusively in the household (60 women) and those engaged in active social activities (64 women). In our opinion, in this case, the decisive factor is cultural and historical characteristics and ideas about gender roles, instilled in the system of national education. With regard to the results themselves, they demonstrate the distribution of maternal-adolescent relationships according to their perceptions of women's social roles (Table 1).

So, according to primary data, the mother, who is more characterized by the perception of a woman as a "housewife," shows a preference for such types of interaction as symbiosis (32,8 \%) and infantilization $(31,1 \%)$. Meanwhile, mothers who allow the role of a "socially active woman" show a tendency to interact in the style of cooperation $(33,3 \%)$ and authoritarianism $(37,5 \%)$. The detected differences are manifested not only in frequency analysis, but also in statistical comparison of the data of the two conditional groups of subjects. It deserves particular attention that, according to the preference of the style, a relationship characterized by emotional disregard, no significant differences were found between mothers with different ideas about women's social roles (Table 2).

Thus, statistical analysis reveals a differential pattern between maternal scores in the area of their preferred child relationship styles, depending on differences in perceptions of women's social roles. In our view, the representation of mothers confining women mainly to the household shows an association with styles such as symbiosis and infantilisation due to the fact that the role of a «housewife» involves a higher frequency of interaction with the child. The latter probably develops a stronger sense of unity among mothers with the child, reinforces their desire to limit themselves from problems and fully satisfy their needs. In addition, the increased frequency of interaction with the child gives greater opportunities to control its behavior, which most likely makes mothers more sensitive to changes in the child, increases their anxiety. The latter is possible under certain conditions to develop such a style of attitude towards the child, which is distinguished by increased infantilization.

As noted above, mothers whose representation reflects not only the role of "housewife" but also the role of "socially active woman" tend to adopt a cooperative or authoritarian style of relationship with a teenage child. This phenomenon, in our opinion, can be explained by the fact that women who allow wider social activity, as a rule, are distinguished by greater initiative, independence, a desire to assert themselves, openness to new experiences, relative autonomy from the opinions of others. Of course, with such a set of individual qualities, the person is most likely inclined to equal relations, the development of independence in a partner, in controversial issues to take his position, which undoubtedly opens up opportunities for the development of cooperative relations. In this regard, at first glance, it does not seem clear that a large percentage of mothers who allow a woman to play the role of a "housewife" and, in parallel, a "socially active woman," among those who prefer an authoritarian style of relations with children. We assume that there is a bilateral mechanism: a woman who, due to excessive social employment, is forced to devote less time to children in the case of one set of personal qualities, seeks to compensate for lost through a greater desire for support, showing interest in the child, but with the predominance of other personality traits begins to demand strict discipline, complete obedience (authoritarianism). In any case, there is another confirmation of the methodological postulate on the refraction of the external through the internal, when the external circumstances of a woman's vital 
Ratio of mothers with different perceptions of women's social roles in preferred styles of attitudes towards adolescent children (percentage)

\begin{tabular}{|c|c|c|c|c|c|c|}
\hline \multirow[b]{2}{*}{ № } & \multirow[b]{2}{*}{ Conditional groups } & \multicolumn{5}{|c|}{ Child Attitude Style } \\
\hline & & 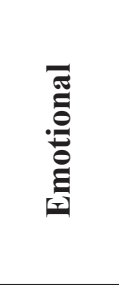 & 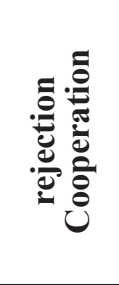 & 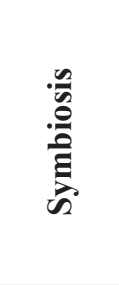 & 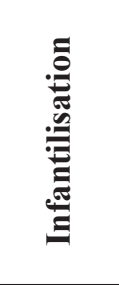 & 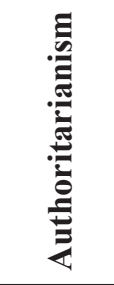 \\
\hline 1 & $\begin{array}{l}\text { Mothers perceiving a woman more as a «housewife» } \\
\left(\mathrm{n}_{1}=76\right)\end{array}$ & $13,1 \%$ & $8,3 \%$ & $32,8 \%$ & $14,7 \%$ & $31,1 \%$ \\
\hline 2 & $\begin{array}{l}\text { Mothers who perceive a woman as both a «housewife» and a } \\
\text { «socially active woman» }\left(\mathrm{n}_{2}=48\right)\end{array}$ & $12,5 \%$ & $30,3 \%$ & $8,3 \%$ & $32,5 \%$ & $8,3 \%$ \\
\hline
\end{tabular}

Table 2

Indicators of statistical difference between maternal data with different perceptions of women's social roles (by Student's t-test)

\begin{tabular}{|c|c|c|c|c|c|}
\hline \multirow{2}{*}{ № } & \multirow[b]{2}{*}{ Child Attitude Style } & \multicolumn{2}{|c|}{ Average indicators of conditional groups } & \multicolumn{2}{|c|}{ Statistical difference indicators } \\
\hline & & $\mathrm{M}_{1}$ & $\mathrm{M}_{2}$ & $\mathrm{t}$ & $\mathrm{p}$ \\
\hline 1 & Emotional rejection & 18.23 & 17,41 & 1,39 & $P \geq 0,05$ \\
\hline 2 & Cooperation & 2,78 & 5,12 & 3,07 & $P \leq 0,01$ \\
\hline 3 & Symbiosis & 5,85 & 3,31 & 2,72 & $\mathrm{P} \leq 0,01$ \\
\hline 4 & Authoritarianism & 1,82 & 4,63 & 2,70 & $P \leq 0,01$ \\
\hline 5 & Infantilization & 5,67 & 3,42 & 2,02 & $\mathrm{P} \leq 0,05$ \\
\hline
\end{tabular}

activity refracted through her internal individuality leads to different results, including in the field of relations with the child.

Research work on the relationship between mothers' perceptions of women's social roles and their preferred patterns of interaction with children thus leads to the following conclusions:

1. In the mother-child relationship system, not only the roles that mothers own but also the perception of them can be an important determinant of their characteristics.

2. For mothers, in whose ideas the role of a woman is limited to the household, the attitude with the child is more characteristic of the type of "symbiosis" and "infantilization," while in the case of mothers with ideas about a woman not only as a "housewife," but also a socially active woman, there is a tendency to such styles as "cooperation" and "authoritarianism."

3. The absence of significant differences between mothers who differ in the criterion of their ideas about the social roles of women, in terms of preference for the style of relationship with the child, based on emotional acceptance or disregard, shows the existence of deeper foundations of maternal attitude in this area.

\section{Використані літературні джерела}

1. Белогай K.H. Структурные компоненты родительского отношения личности: автореф. дис. ... к. психол. н. Кемерево : КГУ, 2006. 24 с.
2. Гериг Р., Зимбардо Ф. Психология и жизнь. 16-е изд. СПб. : Питер, 2004. 955 с.

3. Гричкевич Т.И. Реформатор: социальная роль или особенности личностных черт. Вестник ВГУ. 2009. № 2. C. 140-148.

4. Клочко Ю.Н., Ермилова Н.Ю., Клочко А.Ю. Социализация личности, ее социальный статус и социальная роль. Вестник СевКавГТУ. 2004. № 1 (11). C. $45-53$.

5. Овчарова P.B. Психология родительства: учеб. пособие для студ. высш. учеб. заведений. М. : Академия, 2005. $368 \mathrm{c.}$

6. Овчарова Р.В. Родительствокакпсихологический феномен: учеб. пособие. М. : Москов. психол.-социал. ин-т, 2006. 496 с.

7. Почебут Л.Г. Личность в группе. Психология: учебник / отв. ред. А.А. Крылов. 2-е изд., перераб. и доп. М. : Проспект, 2004. С. 381-398.

8. Станкин М.И. Социальная роль. Специалист. 2004. № 2. C. 25-29.

9. Абдуллаева Д.У. Детско-родительские отношения как фактор развития креативности детей. Развитие интеллектуально-творческого потенциала молодежи: из прошлого в современность: материалы Междунар. очно-заочной науч.-практ. конф. 2018. C. $335-336$.

10. Абдуллаева Д.У. К вопросу об этнических особенностях взаимоотношений ребёнка с матерью отношения (на основе историко-этнологических материалах узбекского этноса). Вестник интегративной психологии. 2018. № 17. С.23-26. 
11. Abdullaeva D.U. The woman's imagination as a mother about herself and the related features of her child attitude to her. Modern views and research: Materials of the international scientific and practical conference. London, 2020. P. 59-63.

\section{References}

1. Belogaj, K.N. (2006). Strukturnye komponenty roditel'skogo otnoshenija lichnosti [Structural components of the parental relationship of personality]. Extended abstract of candidate's thesis. Kemerevo. $24 \mathrm{p}$.

2. Gerig R., \& Zimbardo F. (2004). Psihologija i zhizn' [Psychology and life]. $16^{\text {th }}$ ed. St. Peterburg, $955 \mathrm{p}$.

3. Grickevich, T.I. (2009). Reformator: social'naja rol' ili osobennosti lichnostnyh chert. [Reformer: social role or features of personal traits]. Vestnik $V G U-$ Bulletin of the Higher State University. 2. P. 140-148.

4. Klochko, Ju.N., Ermilova, N.Ju., Klochko, \& A.Ju. 2004. Socializacija lichnosti, ee social'nyj status i social'naja rol' [Socialization of personality, its social status and social role]. Vestnik SevKavGTU - Bulletin of SevKavSTU. 1 (11). P. 45-53.

5. Ovcharova, R.V. (2005). Psihologija roditel'stva [Psychology of Parenthood]. Moscow: Academy, $368 \mathrm{p}$.

6. Ovcharova, R.V. (2006). Roditel'stvo kak psihologicheskij fenomen [Parenthood as a psychological phenomenon]. Moscow. $496 \mathrm{p}$.

7. Pochebut, L.G. (2004). Lichnost' v gruppe. Psihologija [Psychology]. Moscow. P. 381-398.

8. Stankin, M.I. (2004). Social'naja rol' [Social role]. Specialist-Expert. 2. P. 25-29.

9. Abdullaeva, D.U. (2018). Detsko-roditel'skie otnoshenija kak faktor razvitija kreativnosti detej [Childparental relations as a factor in the development of children's creativity]. Razvitie intellektual'no-tvorcheskogo potenciala molodezhi: iz proshlogo $v$ sovremennost' Development of the intellectual and creative potential of youth: from the past to the present. Materials of the international scientific and practical conference P. 335-336.

10. Abdullaeva, D.U. (2018). K voprosu ob jetnicheskih osobennostjah vzaimootnoshenij rebjonka $\mathrm{s}$ mater'ju otnoshenija (na osnove istoriko-jetnologicheskih materialah uzbekskogo jetnosa) [On the issue of the ethnic features of the relationship between the child and the mother of the relationship (based on historical and ethnological materials of the Uzbek ethnic group)].
Vestnik integrativnoj psihologii - Bulletin of integrative psychology. 17. P. 23-26.

11. Abdullaeva, D.U. (2020). The woman's imagination as a mother about herself and the related features of her child attitude to her. Modern views and research: Materials of the international scientific and practical conference. London. P. 59-63.

Абдуллаєва Ділбар Убайдуллаевна. Співвідношення матерів 3 різними уявленнями про соціальні ролі жінок.

Анотація.

У статті розглянуто проблему дитячо-батьківських відносин у контексті індивідуальної психологіі матерів. На основі емпіричних даних автор розкриває роль уявлень матерів про сочіальні ролі жінок у визначенні особливостей їх ставлення до дітей. Згідно з отриманими даними, доводиться взаємозв'язок між переважсаючими стилями дитячо-батьківських відносин і уявленнями матерів про жінку в ролі «домогосподарки» $i$ «соиіально активної особистості».

Так, науково-дослідна робота, щзо спрямована на вивчення взаємозв'язку між уявленнями матерів про соиіальні ролі жінки та моделями взаємодії з дітьми, дає змогу визначити таке:

1. У системі взаємовідносин «мати-дитина» важливим фактором, що визначае їх особливості, можуть виступати не лише самі ролі, якими володіють матері, а й уявлення про них.

2. Для матерів, в уявленнях яких роль жінки обмежується домашнім господарством, більш характерним є налагодження з дитиною відносин по типу «симбіоз» $i$ «інфантилізаиї», тоді як у матерів з уявленнями про жінку не лише як про «домогосподарку», а й про соџіально-активну особистість, спостерігається схильність до таких стилів, як «кооперація» $i$ «авторитаризм».

3. Відсутність істотних відмінностей між матерями, відрізняються за критерієм їх уявлень про соиіальні ролі жінки, по частині переваги стилю взаємин з дитиною, на основі емоційного прийняття або ігнорування, показує наявність більш глибинних основ материнських відносин у иій сфері.

Ключові слова: уявлення; психологічний фактор; соціальна роль; діти-підлітки; дитячо-батьківські відносини; материнське ставлення. 